\title{
АНАЛІЗ СТАТИСТИЧНИХ ДАНИХ ЩОДО ОРГАНІЗАЦІЇ ШВИДКІСНОГО РУХУ НА МЕРЕЖІ ЗАЛІЗНИЦЬ УКРАЇНИ
}

Канд. техн. наук О. Е. Шандер, асист. Ю. В. Шандер, магістранти А. Ю. Гнатенко, Ю. М. Зінченко

\section{ANALYSIS OF STATISTICAL DATA ON THE ORGANIZATION OF SPEED MOVEMENT ON THE NETWORK OF UKRAINIAN RAILWAYS}

PhD (Tech.) O. Shander, assistant Yu. Shander, masters A. Yu. Gnatenko, Yu. M. Zinchenko

DOI: https://doi.org/10.18664/1994-7852.185.2019.180618

У роботі проведено аналіз статистичних даних пасажирських перевезень на мережі залізниць Украӥни, виділено основні завдання для майбутньої організації швидкісного руху в умовах інтеграції України до ЄС. Проведено аналіз функиіонування швидкісних пасажирських перевезень в різних країнах світу та запропоновано можливі варіанти розвитку швидкісних перевезень з урахуванням мінімізачії часу слідування пасажирів між основними містами.

Ключові слова: організація швидкісного руху, залізнична мережа, швидкісні поӥзди.

The article analyzes the current state of passenger traffic on the railway network of Ukraine, identifies the main tasks for the future organization of high-speed traffic in conditions of Ukraine's 
integration into the EU. The analysis of the operation of high-speed passenger transportation in different countries of the world is carried out and possible variants of development of high-speed transport are offered, taking into account minimization of expenses for construction and time of passengers' passage between the main cities. Many years of foreign experience in the design and operation of high-speed roads, despite the differences in socio-economic, geological, topographical, and demographic conditions in different countries, has proved the expediency of two ways to solve the problem of speed, such as speeding traffic on existing lines; construction and commissioning of specialized high-speed lines. It is proved that introduction of high-speed passenger trains on the main railway lines will: significantly increase the capacity of railway transport in the field of passenger transportation; reducing the time spent by passengers on the road and ensuring that on this basis, the needs of the population in the implementation of travel; reduction of the cost of passenger transportation and the expenses of society to eliminate the consequences of transport; creation of a competitive environment in the market of transport services; ensuring integration of the country's railways into the European transport system. It is proved that in order to ensure introduction of high-speed traffic in certain directions it is necessary to carry out a set of measures for technical re-equipment of railway sections, nodes, railroad, car and locomotive economy, and other objects of infrastructure of railways. Therefore, in the long run, the task of introducing high-speed passenger trains with a speed of up to $350 \mathrm{~km} / \mathrm{h}$, should be set as it is the most resource-saving mode of transport.

Keywords: organization of high-speed traffic, railway network, high-speed trains.

Вступ. В умовах інтеграції України до ЄС важливою $є$ необхідність формування єдиних стандартів організації залізничних пасажирських перевезень. Завдяки своєму географічному розташуванню Україна протягом тисячоліття служить містком між Свропою та Азією і є важливим елементом розвитку транспортних стратегій різних країн. У всіх розвинених країнах світу швидкісний пасажирський рух залізниць відіграє провідну роль у житті суспільства та $\epsilon$ однією з базових галузей економіки. Тому важливим складником $\epsilon$ розвиток організації швидкісного руху.

Одним із великомасштабних залізничних проектів в умовах реформування галузі $\epsilon$ впровадження швидкісного пасажирського руху між основними містами 3 найбільшими пасажиропотоками. Дуже вигідне географічне положення нашої держави служить основою для збільшення як вантажопотоків, так і пасажиропотоків у напрямку Свропа-Азія. Якщо врахувати, що через нашу країну проходить декілька важливих міжнародних транспортних коридорів, то відповідні умови надають можливість підвищити конкурентоспроможність залізничного транспорту.

Мережа маршрутів швидкісних поїздів в Україні має дуже широкий спектр. Наразі об'єднано Київ 3 найбільшими промисловими та культурними центрами України, такими як Запоріжжя, Дніпро, Харків, Львів, Тернопіль, Трускавець, Одеса. Тому важливим кроком подальшого розвитку є впровадження швидкісного руху на всій мережі залізниць та з'єднання швидкісних ліній між Азією та Свропою. А якщо врахувати затверджену «Транспортну стратегію України на період до 2020 року», то можна зробити висновок, що дана тема $\epsilon$ актуальною.

Аналіз останніх досліджень та публікацій. Вагомий внесок у розроблення теоретичних засад з впровадження швидкісного руху зробили такі науковці: Бутько Т. В., Калашнікова Т. Ю., Константінов Д. В., Малахова О. А., Момот А. В., Пархоменко Л. О., Прохорченко А. В., Krink J., Palacin R., Jianping Z., Liebchen C. Значна кількість наукових робіт $[1,3,5,6$, $10,11]$ аналізує перспективи розвитку високошвидкісних залізниц на основі 
закордоного досвіду. У роботах $[1,2,4,7$, 8] проаналізовано наукові підходи щодо розрахунку основних параметрів високошвидкісних магістралей. У дослідженні [11] розглянуто питання пропускної спроможністі залізничних швидкісних ліній. Дослідження ефективності організації швидкісного руху на залізницях України на основі економічних підходів та їх недоліки проаналізовано в роботах $[14,16,17]$. На основі концепції Державної цільової програми впровадження на залізницях швидкісного руху вантажних поїздів визначено основні задачі впровадження на залізницях України мережі швидкісних залізничних магістралей для сполучення України з основними великими центрами, а також з країнами СНД та Свропи. Аналіз цих наукових досліджень доводить, що більшість робіт мало враховує питання реалізації напряму "Україна-Свропа" 3 впровадження швидкісного руху. Тому важливим $\epsilon$ аналіз статистичних даних щодо організації швидкісного руху на мережі залізниць україни та формування пропозицій 3 урахуванням транспортних стратегій різних країн.

Визначення мети та завдання дослідження. Метою статті $\epsilon$ аналіз статистичних даних щодо організації швидкісного руху на мережі залізниць України, аналіз світового досвіду впровадження швидкісних пасажирських перевезень та визначення перспектив розвитку швидкісних перевезень в Україні в умовах євроінтеграції. Основним завданням $\epsilon$ формування пропозиції щодо впровадження швидкісного руху на мережі залізниць України з урахуванням світового досвіду та сучасних умов функціонування залізничного транспорту.

Основна частина дослідження. Для вибору концепції розвитку швидкісного руху пасажирських поїздів необхідним $\epsilon$ проведення досліджень закордонного досвіду 3 організації пасажирських перевезень. На основі аналізу функціонування залізничного транспорту можна виділити основні моделі організації залізничного ринку: європейську, північноамериканську та змішану.

Найбільш розповсюдженою та більш сприятливою для залізниць України $\epsilon$ європейська модель організації залізничних перевезень. Основною ідеєю відповідної моделі $\epsilon$ монопольне становище держави щодо інфраструктури об'єтів та можливість управління рухом поїздів. Основними $\epsilon$ залізничні холдинги, які належать державі. Ринок пасажирських перевезень в країнах ЄС грунтується на змішаній моделі, що надає можливість компаніям конкурувати між собою та підвищувати рівень пасажирських превезень.

У Європі існує три типи залізничної інфраструктури залежно від організації пасажирських перевезень та дозволеної швидкості ліній. Вони поділяються на категорії. На класичних лініях допускається швидкість до 160 км/год. Дана категорія відноситься до залізниць змішаного типу перевезень, де переважно використвуються лінії 3 вантажними поїздами. Тому щвидкість на таких лініях різноманітна $\mathrm{i}$ часто нижча за теоретичну. Високошвидкісні класичні залізниці - це наступний крок до справжнього високошвидкісного руху, так як допускається швидкість до 200 км/год. Високошвидкісні залізниці визначаються Міжнародним союзом залізниць та допускають швидкість понад 200 км/год, а на деяких нових лініях понад 250 км/год. Високошвидкісні залізниці Франції, Іспанії, Німеччини, Бельгії, Нідерландів, Італії та Великобританії мають проектну швидкість 300 км/год та більше. Світовим рекордсменом зі швидкості залізничних ліній $є$ Франція із зареєстрованою швидкістю 575 км/год на показовому пробігу 2007 р. між Парижем та Страсбургом.

Проведений аналіз розподілу перевезень по швидкісних залізничних лініях довів, що лідерами високошвидкісного 
руху є Японія (близько 40 \%), Китай (25\%) | та Франція (близько $15 \%$ ) (рис. 1) [16].

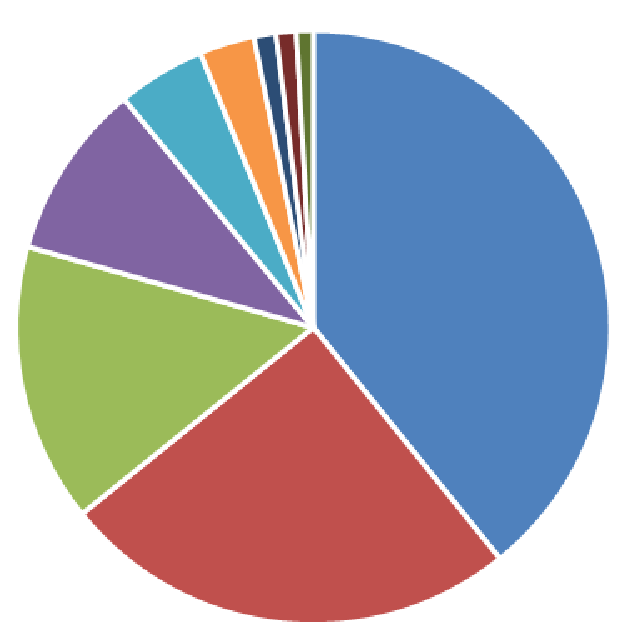

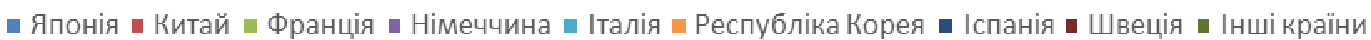

Рис. 1. Діаграма кількості швидкісних ліній в різних країнах світу

Багаторічний зарубіжний досвід проектування та експлуатації швидкісних залізниць довів, що доцільним є два способи вирішення питань підвищення швидкостей. Перший спосіб враховує організацію швидкісного руху на наявних залізничних лініях, а другий передбачає будівництво спеціалізованих швидкісних магістралей.

У звязку 3 цим, якщо розглядати організацію швидкісного руху на наявних лініях, одним із пріоритетних напрямків $\epsilon$ можливість закупівлі полегшених поїздів у іспанської компанії Talgo. Так як Укрзалізниця (УЗ) працює над розвитком сполучення 3 країнами ЄС та інтеграцією української залізничної системи в європейську, то придбання відповідного рухомого складу підвищить швидкість руху поїздів, зокрема у напрямку Польщі, Австрії, Угорщини. Для цього потенційно можно розглядати варіанти застосування рухомого складу, оснащеного системою автоматичної зміни ширини колії. У цьому сегменті компанія Talgo також $є$ провідним виробником.

Компанія Talgo має значний досвід виготовлення швидкісних потягів, зокрема i для нешвидкісних колій. Рухомий склад іспанська компанія пристосовує до кліматичних умов місцевості. Він витримує i високі, і низькі температури, має менші витрати на обслуговування, меншу вагу i розвиває великі швидкості. Компанія, на підставі оцінки наявної в Україні залізничної інфраструктури, здійснить моделювання i надасть попередні рекомендації щодо можливостей i умов збільшення швидкості руху поїздів Talgo на існуючій інфраструктурі ПАТ «Укрзалізниця». Відповідний рухомий склад вже використовується в країнах СНД і дуже добре себе зарекомендував.

Компанія виробляє найлегші вагони у світі, використовуючи під час їх виготовлення екструдовані алюмінієві профілі, що забезпечують максимальні показники міцності конструкції. Вага вагона Talgo майже на $30 \%$ менша за вагу вагонів інших виробників. Це дає можливість збільшити швидкість руху до 180-220 км/год.

Якщо проаналізувати сучасний стан швидкісних перевезень в Україні, то можна визначити основні переваги, які надає Українська залізнична швидкісна компанія: 
час подорожі; вартість перевезень; доступність для пасажирів; точність та надійність; комфорт; зручний розклад руху; сервіс [13].

Власне швидкісними потягами (максимальна швидкість до 160 км/год) зараз є потяги на таких напрямках:

Київ-Полтава-Харків (Hyundai, Scoda) 4 рази на день;

Київ-Лозова-Костянтинівка (Hyundai) 1 раз на день;

Київ-Коростень-Львів (Hyundai) - 1 раз на день;

Київ-Дніпро (Hyundai) - 2 рази на день;

Київ-Львів-Перемишль - 2 рази на день;

Київ-Одеса - 1 раз на день;

Київ-Львів-Івано-Франківськ - 1 раз на день.

За липень 2018 р. швидкісні поїзди Укрзалізниці перевезли 540 тис. осіб. Даний показник є найбільшим з початку впровадження в Україні швидкісних залізничних перевезень.

На даний час середня заповненість складає більше $90 \%$, що є дуже важливим показником 3 точки зору подальшого впровадження швидкісних перевезень.

У минулому році швидкісні потяги здійснили більш 4 тис. рейсів. Популярним $\epsilon$ харківський напрямок - 1.154 млн пасажирів. Рейсами в Дніпро і назад перевезено 1.012 млн пасажирів, із Львова і назад 635 тис. пасажирів, із Одеси і назад 378 тис. пасажирів.

У 2017 р. вперше за довгий час У3 призначила новий міжнародний потяг Київ-Перемишль. У листопаді 2016 р. було відновлено рух швидкісного потяга у Кривий Ріг, а задяки тому, що було відремонтовано двоповерховий потяг Skoda, введено маршрут Харків-Київ-Вінниця.

В липні 2018 р. швидкісні поїзди здійснили 847 рейсів. У порівнянні 3 липнем минулого року кількість пасажирів зросла на 27000 осіб. Населеність швидкісного рухомого складу було на рівні $96 \%$. 3 початку року поїзди Української залізничної швидкісної компанії перевезли майже 3,3 млн пасажирів [18].

На рис. 2 наведено загальне збільшення пасажиропотоку на Укрзалізниці $[12,15]$.
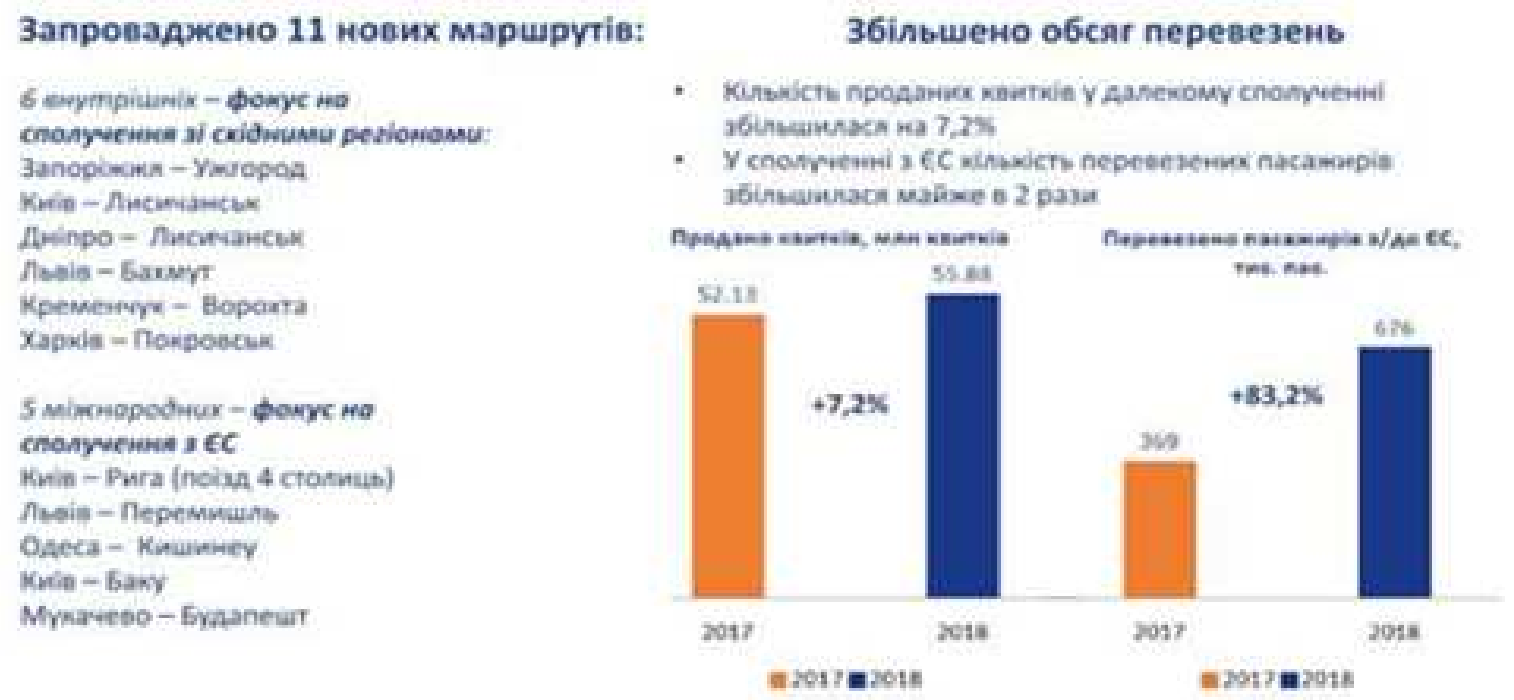

Рис. 2. Динаміка збільшення пасажиропотоків за 2017-2018 рр.

На основі проаналізованих даних доведено, що найбільш затребувані напрямки потягів із Києва - Київ-Одеса,
Київ-Львів, Київ-Лисичанськ, Київ-Харків, Київ-Херсон, Київ-Миколаїв; із Харкова Харків-Херсон; із Львова - Львів-Київ, 
Львів-Одеса; із Одеси - Одеса-Київ, ОдесаІвано-Франківськ; із Дніпра - Дніпро-Київ, Дніпро-Одеса, Дніпро-Трускавець, ДніпроХарків; із Запоріжжя - Запоріжжя-Київ, Запоріжжя-Львів, Запоріжжя-Харків, Запоріжжя-Одеса; із Херсона - ХерсонКиїв, Херсон-Миколаїв; із Костянтинівки Костянтинівка-Київ; із Кривого Рогу Кривий Ріг-Київ.

Якщо розглядати європейський досвід, то прийнято обмежувати термін швидкісної поїздки до 8 год, а в Україні поки встановлена межа 7 год. 3 позиції конкуренції 3 авіаційним транспортом термін поїздки не повинен перевищувати 4,5-5 год, тому що за правилами аерофлоту пассажир мусить приїхати на реєстрацію за 1,5-2 год, час подорожі у межах України становить близько 1 год, отримання багажу та збільшення терміну поїздки до аеропорту та в зворотному напрямку - 1-1,5 год. На основі вказаних термінів поїздки відстані курсування швидкісних поїздів в Україні повинні бути до 8 год. Тобто швидкісні поїзди в Україні можуть курсувати на відстань до 1100 км. Виходячи із сказаного вище можна зазначити, що в Україні доцільно впровадити швидкісний рух майже в усіх напрямках.

На основі аналізу можливими варіантами розвитку швидкісних магістралей для України $\epsilon$ поетапне збільшення швидкості:

- 3 160-200 км/год;

- 3 200-250 км/год;

- 3 250-350 км/год (на основних ділянках).

На основі світового досвіду будівництво високошвидкісних магістралей необхідно проектувати та вводити поетапно, за підтримки фінансування державою i інвестиційними компаніями. Одним із важливих завдань $\epsilon$ реалізація швидкісного руху на напрямку із України до Європи. Потрібно зв'язати основні міста нашої країни 3 великими містами європейських країн. На даний час середня швидкість руху поїздів між європейськими містами складає близько 55-60 км/год. Даний показник не відповідає основним євпопейським нормам i тому основним етапом $\epsilon$ організація високошвидкісного залізничного руху на напрямок "УкраїнаСвропа", так як відповідний напрямок $\epsilon$ одним із перспективних та покращить мобільність населення.

Одними 3 перспективних напрямків $\epsilon$ Львів - Вроцлав, Львів - Братислава, Львів - Будапешт, Львів - Краків. Запуск на відповідних ділянках швидкісного руху забезпечить скорочення часу проходження поїздом між основними європейськими містами та підвищить сервіс обслуговування. Для зменшення часу в дорозі та підвищення швидкості руху на вказаних ділянках необхідно модернізувати колію, контактну мережу, пристрої автоматики і сигналізації та ряд станцій. Bci заходи потрібно привести до норм, які забезпечать функціонування швидкісних перевезень на напрямку "Україна-Свропа".

Напрямок "Україна-Свропа" підвищить зв'язність територій України 3 європейськими країнами, а реалізація відповідного проекту дозволить інтегруватися в єдину високошвидкісну мережу Європейського Союзу. В табл. 1 наведено перспективні напрямки руху швидкісних поїздів.

Визначення напрямків високошвидкісних магістралей, a також порядок впровадження швидкісного руху на них повинні здійснюватися 3 урахуванням витрат на будівництво мережі високошвидкісних ліній, розвитку туристичних напрямків, недопущення транспортного роз'єднання основних міст i погіршення транспортного сполучення 3 іншими сусідніми країнами, можливості i доцільності функціонування денних поїздів на мережі України. Передбачувані напрямки швидкісного руху в межах України наведено в табл. 2.

Існуючі і перспективні напрямки руху поїздів 
Збірник наукових праць Українського державного університету залізничного транспорту

\begin{tabular}{|l|c|c|c|c|}
\hline & $\begin{array}{c}\text { Відстань, } \\
\text { км }\end{array}$ & $\begin{array}{c}\text { Час у дорозі на } \\
\text { даний час, год }\end{array}$ & $\begin{array}{c}\text { Середня } \\
\text { швидкість в } \\
\text { дорозі, км/год }\end{array}$ & $\begin{array}{c}\text { Час в дорозі при } \\
\text { швидкості } \\
160-200 \text { км/год }\end{array}$ \\
\hline Київ - Мінськ & 620 & 10,0 & 63 & $3,0-3,5$ \\
\hline Львів - Вроцлав & 607 & 10,0 & 58 & $3,0-3,5$ \\
\hline Львів - Краков & 339 & 7,0 & 51 & $1,5-2,5$ \\
\hline Львів - Будапешт & 578 & 14,0 & 43 & $3,0-3,5$ \\
\hline Львів - Братислава & 816 & 17,0 & 45 & $5,0-5,5$ \\
\hline
\end{tabular}

Таблиця 2

Запропоновані напрямки швидкісного руху

\begin{tabular}{|l|c|}
\hline \multicolumn{1}{|c|}{ Напрямок швидкісного руху } & Відстань, км \\
\hline Київ - Полтава & 336 \\
\hline Київ - Одеса & 652 \\
\hline Київ - Вінниця - Львів & 450 \\
\hline Львів - Івано-Франківськ & 135 \\
\hline Полтава - Харків & 155 \\
\hline Полтава - Дніпропетровськ (в обхід Краснограда) & 195 \\
\hline Полтава - Лозова - Костянтинівка & 350 \\
\hline Одеса - Миколаїв - Кривий Ріг - Дніпропетровськ & 490 \\
\hline Львів - Мукачево & 230 \\
\hline Дніпропетровськ - Синельниково - Новоолексіївка & 322 \\
\hline Запоріжжя - Маріуполь & 301 \\
\hline
\end{tabular}

Запропоновані напрямки швидкісного руху розглядаються 3 використанням основних показників: витрати на будівництво мережі та час доставки пасажирів. Тобто повинна вирішуватися задача мінімізації витрат на будівництво та часу доставки пасажирів між основними містами.

Для забезпечення впровадження швидкісного руху на запропонованих напрямках потрібно здійснити комплекс заходів 3 технічного переоснащення об'єктів інфраструктури залізниць [20].

Висновок. Основним напрямом розвитку та функціонування залізничного транспорту України $є$ впровадження швидкісного пасажирського руху.
Основним завданням на першому етапі $\epsilon$ удосконалення та створення швидкісних магістралей, а в подальшому впровадження високошвидкісних ліній. Введення в експлуатацію швидкісного руху на території України $є$ дуже складним питанням та потребує багатьох років. На основі закордонного досвіду можна зробити висновок, що від якості виконаних робіт залежить не лише конкурентоспроможність залізничного транспорту нашої держави, але i авторитет на міжнародному рівні. Впровадження високошвидкісних магістралей в країні буде вигідним не тільки Україні, але i Європі, та буде потужним імпульсом для розвитку нашої країни.

Список використаних джерел 
1. Шандер О.Е., Леміш А. М. Удосконалення процесу організації пасажирських швидкісних перевезень в умовах пересадок. Зб. наук. праць Укр. держ. ун-ту залізнич. трансn. 2017. Вип. 173. С. 176-183.

2. Krink J.,Vesterstrom, and Riget J. Particle Swarm Optimization with Spatial Particle Extension. To appear in: Proceedings of the Congress on Evolutionary Computation, 2002 (CEC 2002).

3. Пархоменко Л. О. Дослідження напрямків розвитку швидкісного i високошвидкісного пасажирського руху поїздів на залізницях України. 3б. наук. пращьь Укр. держ. акад. залізнич. трансп. 2014. Вип. 145. С. 44-50.

4. Palacin R., Raif L., Deniz Ö., Yan N. High speed rail trends, technologies and operational patterns: a comparison of established and emerging networks. Transport Problems INTERNATIONAL SCIENTIFIC JOURNAL. 2014. Volume 9. Special Edition. P. 18-26.

5. Константінов Д. В., Крамченко К. В. Моделювання процесу оперативного регулювання швидкісних міжрегіональних пасажирських перевезень. Вісник Національного технічного університету "ХПI" : зб. наук. праць. Сер. Нові рішення в сучасних технологіях. 2013. № 56. С. 128-136.

6. Калашнікова Т. Ю., Чередніченко Ю. М. Визначення найкращої моделі використання високошвидкісних магістралей для залізниць України. Зб. наук. пращь Укр. держ. ун-ту залізнич. трансп. 2016. Вип. 162. С. 177-182.

7. Jianping Z. Planning and Development of High-Speed Pail Network in China: презентация доклада на VIII всемирном конгрессе по высокоскоростному железнодорожному транспорту. Филадельфия, 2012. 13. Chinese high speed: in the wake of Wenzhou. International Railway Journal. 2012. № 7. P. 22.

8. Liebchen C., Mohring Rolf H. The Modeling Power of the Periodic Event Scheduling Problem: Railway Timetables — and Beyond. F. Geraets et al. (Eds.): Railway Optimization 2004. 2007. LNCS 4359. P. 3-40.

9. Малахова О. А., Анікєєва О. М. Розвиток швидкісного пасажирського руху в Україні на основі всесвітнього досвіду. Зб. наук. праць Укр. держ. ун- ту залізнич. трансп. 2015. Вип. 154. С. 75-79.

10. Пархоменко Л. О., Серпокрилов В. Ю., Коваленко Д. М. Аналіз динаміки пасажиропотоків по Україні в умовах швидкісних перевезень. Зб. наук. праць Укр. держ. унmу залізнич. трансп. Харків : УкрДУЗТ, 2017. Вип. 173. С. 143-148.

11. Прохорченко А. В., Кравченко Д. О. Аналіз наукових досліджень щодо проектування транспортних мереж високошвидкісного та звичайного руху. 3б. наук. праџь Укр. держ. ун-ту залізнич. трансп. 2015. Вип. 154. С. 70-74.

12. Офіційний веб-сайт Укрзалізниці. URL: http://uz.gov.ua (дата звернення: 05.04.2018).

13. Українська залізнична швидкісна компанія. URL: http://intercity.uz.gov.ua (дата звернення: 07.04.2018).

14. Божок Н. О. Напрямки впровадження швидкісних пасажирських перевезень в Україні. Проблеми економіки транспорту: зб. наук. праць Дніпропетровського національного університету залізничного транспорту імені академіка В. Лазаряна. 2013. Вип. 5. С. 46-56.

15. Офіційний веб-сайт Державної служби статистики України. URL: http://ukrstat.gov.ua (дата звернення: 05.04.2018).

16. Лук'янова О. М. Сучасний стан та перспективи розвитку мережі швидкісних залізничних магістралей в Україні в умовах євроінтеграції. Науковий вісник Ужгородського національного університету. 2018. Вип. 20. Част. 2. С. 107-110. 
17. Момот А. В. Методичний підхід до визначення раціональних швидкостей руху пасажирських поїздів та раціональних зон їх курсування. Проблеми економіки транспорту: зб. наук. праць Дніпропетровського національного університету залізничного транспорту імені академіка В. Лазаряна. 2013. Вип. 5. С. 80-89.

18. Офіційний веб-сайт газети «Магістраль». URL: http://magistral-uz.com.ua (дата звернення: 10.04.2018).

19. Концепція Державної цільової програми впровадження на залізницях швидкісного руху пасажирських поїздів на 2005-2015 роки. Розпорядження Кабінету Міністрів України від 31.12.2004 № 979-p. URL: http://zakon2.rada.gov.ua (дата звернення: 11.04.2018).

20. Офіційний веб-сайт Інституту проектування інфраструктури транспорту. URL: http://ipit.ooo/ua/prospects-for-the-development-of-high-speed-railways-the-railways-of-ukraine (дата звернення: 15.04.2018).

Шандер Олег Едуардович, канд. техн. наук, доцент кафедри управління експлуатаційною роботою Українського державного університету залізничного транспорту. Тел: 0992279859.

E-mail: o.e.shander@gmail.com.

Шандер Юлія Валеріївна, асистент кафедри управління експлуатаційною роботою Українського державного університету залізничного транспорту.

Гнатенко Аліна Юріївна, магістрант, група 11-1-ТТ Українського державного університету залізничного транспорту.

Зінченко Юлія Михайлівна, магістрант, група 11-1-ТТ Українського державного університету залізничного транспорту.

Shander Oleg Eduardovich, PhD (Tech). Associate Professor, department of Management of operational work of the Ukrainian State University of Railway Transport. E-mail: o.e.shander@gmail.com.

Shander Yulia Valerievna, assistant, department of Management of operational work of the Ukrainian State University of Railway Transport.

Gnatenko Alina, master, Group 11-1-TT, Ukrainian State University of Railway Transport. Zinchenko Julia, master, Group 11-1-TT, Ukrainian State University of Railway Transport.

Статтю прийнято 28.05.2019 р. 